\title{
Stock Price Reactions to Publications of Financial Statements: Evidence from the Moscow Stock Exchange
}

\author{
Parmenas Njoroge $\square$ \\ Post Graduate Student, Faculty of Economics \\ ORCID \\ E-mail: ndzhoroge@sfedu.ru \\ Southern Federal University, Rostov-on-Don, Russia
}

\section{Michaela Baumann}

Dr. rer. nat.

Data Scientist

$\underline{\text { ORCID }}$

E-mail: michaela.baumann@nuernberger.de

Nürnberger Lebensversicherung AG, Nürnberg, Germany

\section{Michael Heinrich Baumann}

Dr. rer. nat.

Postdoctoral Researcher, Faculty of Mathematics, Physics, and Computer Science

ORCID

E-mail: michael.baumann@uni-bayreuth.de

University of Bayreuth,

Bayreuth, Germany

\section{Dmitry Shevchenko}

Cand. Sci. (Econ.)

Associate Professor, Faculty of Economics

ORCID

E-mail: dashevchenko@sfedu.ru

Southern Federal University, Rostov-on-Don, Russia

\section{Journal of Corporate Finance Research, Vol. 15, No. 1, pp. 19-36 (2021)}

For citation: Njoroge, P., Baumann, M., Baumann, М. и Shevchenko, D. (2021) «Stock Price Reactions to Publications of Financial Statements: Evidence from the Moscow Stock Exchange», Journal of Corporate Finance Research / Корпоративные Финансы | ISSN: 2073-0438, 15(1), cc. 19-36. doi: 10.17323/j.jcfr.2073-0438.15.1.2021.19-36.

Received 15 January 2021 | Peer-reviewed 13 February 2021 | Accepted 20 February 2021 


\section{Abstract}

This paper analyses the effects of financial statements on the efficiency of the Russian stock market. Specifically, we analyse the impact of financial reporting on stock prices of the firms listed on the Moscow Stock Exchange. By means of the widely used event study method, which dates back to Ball and Brown [1], we analyse how corporate news publication affects stock prices.

Our research analyses 1000 samples, each consisting of 30 events, independent of the underlying stocks/firms and analyses the relation between the behaviour of the share prices and the release of the firms' annual, quarterly, and unscheduled financial statements. We use the daily stock price data of 56 components of the Russia Trading System Index from the years 2014 to 2020 in order to analyse the relation between the behaviour of the shares' prices and the releases of the firms' annual, quarterly, and unscheduled financial statements.

Using an ordinary least squares market model, we estimate the market parameters and especially the so-called normal returns, i.e. benchmark values. With this, we calculate the abnormal returns, i.e. the price changes caused by the events cf. $[1 ; 2]$. We perform several statistical tests for non-Gaussian distribution of these abnormal returns and find that there is a significantly non-Gaussian relationship between the publication of financial statements and the prices of the shares, which should not be the case in an efficient market [2].

Our results indicate that stock price volatility on the publication of financial statements may be caused by some information asymmetry, and demonstrate that the Russian stock market responds significantly to new information. Thus, we discuss recommendations to improve the information content of financial statements in Russia. This means analysts and fund managers can use new information to predict future stock returns and, thus, construct profitable portfolios.

Keywords: market efficiency, financial statements, Russian stock market, emerging markets, event study method, stock price reactions 


\section{Introduction}

A vibrant capital market attracts foreign capital and provides access to capital for firms seeking to raise funds. The Russian capital market has experienced tremendous growth, signposted particularly by the mass privatisation of state enterprises in the 1990s, the merging of the two main Russian exchanges in 2011 to form the MOEX, and Russia's accession to the world trade organisation in 2012. Various reforms have been undertaken in the financial sector, including the partial adoption of international financial reporting standards (IFRS) in 2012 and a continuous review of the Russian Accounting Standards (RAS). These steps have been taken to increase market efficiency, attract investors, and steer growth in the Russian financial sector.

Information disclosure in Russia operates under unique circumstances, as will be discussed later in detail. Note that, firstly, the Russian stock market is relatively young compared to other major stock markets. Secondly, the government is a large shareholder in several major Russian firms. And thirdly, industrial firms make up a significant part of the Russian economy (cf. Figure 1). Thus, investigating the efficiency of the Russian stock market under these unique circumstances is a very relevant topic.

This study examines the behaviour of stock prices around the release of annual, quarterly, and unscheduled financial statements for companies listed in the Moscow Stock Exchange, and more precisely the ones in the Russian Trading System Index (RTS Index). By testing the efficiency of the Russian stock market, i.e., by testing whether publicly available information is included in the stock prices, we seek to understand whether traders can make abnormal profits on the publication of unscheduled, quarterly, and annual financial statements. In an inefficient market, new information is not reflected in stock prices immediately, making it possible that predictable price movements can occur in the market. Analysts try to use fundamental and technical analysis to predict which stocks are over- or undervalued, which may lead to excessive trading, high volatility, and overall unstable financial markets. However, this prediction is only possible in an inefficient market, cf. [2].

We will also seek to identify promising procedures, forms, and requirements for financial statements that ensure adequate information to financial market participants to decrease the difference between the fundamental value and the market value. This study can inform researchers, policymakers, and investors as to how the market responds to publication of annual, quarterly, or other financial statements.

The remainder of the work is organised as follows: we present the review of the literature on stock market reactions to the publication of financial statements. We discuss the Russian economic environment, provide information on the methodology applied in the study outlining data and study procedures, i.e. the event study method. We test the hypothesis that abnormal returns arise upon the publication of annual, quarterly, and unscheduled financial statements. We discusses the results, while concludes with a summary of our key findings as well as recommendations for further studies.

\section{Literature Review}

In this section, we provide an overview of market efficiency studies, i.e. on studies analysing stock market reactions to the publication of financial statements. Further, we will provide background information on Russia's economic environment.

\section{An Overview on Stock Market Reactions to the Publication of Financial Statements}

Fama [3] defined an effective market as one in which all new information is always fully reflected in stock prices. Fama [2] discusses the quick adjustment of prices to new information in efficient markets within one trading day. Any slower reaction would indicate some inefficiency. In efficient markets, all reactions should average out such that it is neither possible to predict future market movements, nor to construct profitable portfolios. We note that the level of efficiency of financial markets varies from country to country. For developed financial markets it is reported that they respond fast to new information. Numerous studies have been made testing market response to different announcements such as earnings announcements, dividends announcements, takeover announcements, and publications of financial statements. Fama, Fisher, Jensen, and Roll [4] investigated 940 stock splits in the New York stock exchange and concluded that a stock market adjusts itself to reflect new information. Other studies, which include Ball and Brown [1], Khanal and Mishra [5], as well as Kothari [6], confirmed that markets respond to earnings and dividends announcements. A suitable methodology to analyse market efficiency is utilised by Jones and Bacon [7], who use the event study method to study earnings announcements in 50 randomly selected firms.

Stock price reactions to the publication of financial statements have been investigated extensively, especially in developed markets. Opong [8] examined the effects of preliminary financial reports on stock prices in the UK. Even though the UK is a developed country, the study finds a significant response on the publication of annual financial statements. Other studies in developed markets include the works of Ball and Brown [1], Beaver [9], Foster [10], and May [11] in the United States and the works of Brookfield and Morris [12] as well as Firth [13] in the UK. Researchers and analysts investigate whether annual, quarterly, and unscheduled financial statements contain any new information $[1 ; 4 ; 14]$. The publication of annual, quarterly or other financial statements might send signals to investors: positive signals cause a rise in stock prices, while negative signals have the opposite effect. In efficient 
markets these responses happen quickly and average out, i.e., there is no trend in these stock price reactions. Note also that in general, steady or rising stock prices indicate good corporate governance whereas declining stock prices indicate poor governance.

Although various literature has documented, an abnormal change in stock prices on the publication of financial statements in developed and emerging markets $[1 ; 3 ; 14]$, research pertaining the Russian financial market are presently few. Menike and Wang [14] investigated stock price reactions to publications of financial statements for companies listed on the Colombo Stock Exchange (Sri Lanka). The study notes that abnormal returns are positive upon the announcement of annual reports, but they are not significant. Rajakulanajagam [15] also investigated stock market reactions to annual financial statements of companies listed on the Colombo Stock Exchange. The study records abnormal returns of stock prices surrounding the publication of financial statements. Choi, Choi, Myers, and Ziebart [16] investigate financial statement compatibility and informativeness on stock prices and found that compatibility improves informativeness and helps investors predicting future prospects. Hayati [17] arrives at the same conclusion in Indonesia. The studies show a relationship between financial statements and stock prices. Berezinets,
Bulatova, Ilina, and Smirnov [18] use the event study method to examine the reactions of exchange-listed Russian firms that regularly pay dividends to their dividend announcements in the post-financial crisis years from 2010 to 2014. They find that markets react negatively to dividends that are both too high and too low. In contrast, we are not interested in the consequences of the financial crisis and do not focus on dividend announcements, but study all announcements. Moreover, we use a more recent data set, which can make a big difference in the young Russian market. Volkov and Sevostyanov [19] also use data from the past-crisis period (from 2009 to 2012) and find no relation between the announcement of financial statements and stock price dynamics. Naidenova and Novikova [20] analyse the reactions of Russia's public companies' stock prices to sanctions against Russia. Garanina and Kormiltseva [21] investigate whether international accounting standards have an influence on the efficiency of the Russian market. However, we seek to understand whether the publication of all financial statements nowadays (from 2014 to 2020) affects the prices of shares listed on the Moscow Stock Exchange - and whether different types of events have a different influence on the stock price dynamics. Table 1 makes a summary of literature on stock prices' reactions to different kinds of news.

Table 1. An overview of selected literature on the effect of various events on stock markets with only a few publications concerning the Russian market

$\begin{array}{llll}\text { Event type } & \text { Author } & \text { Country } & \text { Conclusion } \\ \text { Stock splits } & \begin{array}{l}\text { Fama, Fisher, Jensen, } \\ \text { and Roll (1969) [4] }\end{array} & \text { United States } & \text { Stock market adjusts to reflect new information } \\ & \end{array}$

$\begin{array}{lll}\begin{array}{l}\text { Earning } \\ \text { announcements }\end{array} & \begin{array}{l}\text { Jones and Bacon } \\ (2007)[7]\end{array} \quad \text { United States } \begin{array}{l}\text { Significant abnormal returns emerge on the day of the } \\ \text { announcement }\end{array}\end{array}$

\begin{tabular}{|c|c|c|c|}
\hline & Kothari (2004) [6] & United States & $\begin{array}{l}\text { Discount rate shocks explain a significant fraction of } \\
\text { aggregate stock returns }\end{array}$ \\
\hline & Beaver (1968) [9] & United States & $\begin{array}{l}\text { The behaviour of the price changes supports the conjec- } \\
\text { ture that earning reports possess information content }\end{array}$ \\
\hline $\begin{array}{l}\text { Dividends } \\
\text { announcements }\end{array}$ & $\begin{array}{l}\text { Khanal and Mishra } \\
\text { (2017) [5] }\end{array}$ & United States & $\begin{array}{l}\text { Significant abnormal returns emerge on the day of the } \\
\text { announcement }\end{array}$ \\
\hline
\end{tabular}

Berezinets, Bulatova, Russia Markets react negatively to both too-high and too-low Ilina, and Smirnov dividends

(2015) [18]

\begin{tabular}{|c|c|c|c|}
\hline \multirow{4}{*}{$\begin{array}{l}\text { Publication } \\
\text { of financial } \\
\text { statements }\end{array}$} & $\begin{array}{l}\text { Dsouza and Mallikar- } \\
\text { junappa (2016) [22] }\end{array}$ & India & $\begin{array}{l}\text { There is strong evidence that the Indian stock market is } \\
\text { inefficient }\end{array}$ \\
\hline & $\begin{array}{l}\text { Rajakulanajagam } \\
\text { (2015) [15] }\end{array}$ & Sri Lanka & $\begin{array}{l}\text { Abnormal returns of stock prices surround the publica- } \\
\text { tion of financial statements }\end{array}$ \\
\hline & $\begin{array}{l}\text { Menike and Wang } \\
\text { (2013) [14] }\end{array}$ & Sri Lanka & $\begin{array}{l}\text { Abnormal returns are positive upon announcement of } \\
\text { annual reports but are not significant }\end{array}$ \\
\hline & Hayati (2010) [17] & Indonesia & $\begin{array}{l}\text { Compatibility improves the informativeness and helps } \\
\text { investors predict future prospects }\end{array}$ \\
\hline
\end{tabular}




\begin{tabular}{|c|c|c|c|}
\hline Event type & Author & Country & Conclusion \\
\hline \multirow{10}{*}{$\begin{array}{l}\text { Publication } \\
\text { of financial } \\
\text { statements }\end{array}$} & $\begin{array}{l}\text { Naser and Nuseibeh } \\
(2002)[23]\end{array}$ & Saudi Arabia & Financial statements shape investors' decisions \\
\hline & Opong (1996) [8] & $\begin{array}{l}\text { United } \\
\text { Kingdom }\end{array}$ & $\begin{array}{l}\text { Stock prices adjust rapidly to the publicly available infor- } \\
\text { mation }\end{array}$ \\
\hline & $\begin{array}{l}\text { Brookfield and Morris } \\
\text { (1992) [12] }\end{array}$ & $\begin{array}{l}\text { United } \\
\text { Kingdom }\end{array}$ & $\begin{array}{l}\text { Stock prices adjust rapidly to the publicly available infor- } \\
\text { mation }\end{array}$ \\
\hline & Firth (1981) [13] & $\begin{array}{l}\text { United } \\
\text { Kingdom }\end{array}$ & $\begin{array}{l}\text { Stock prices adjust rapidly to the publicly available infor- } \\
\text { mation }\end{array}$ \\
\hline & Foster (1977) [10] & United States & Markets react to quarterly earnings announcements \\
\hline & May (1971) [11] & United States & There is information in quarterly announcements \\
\hline & $\begin{array}{l}\text { Ball and Brown (1968) } \\
{[1]}\end{array}$ & United States & $\begin{array}{l}\text { The study finds a significant response on publication of } \\
\text { annual financial statements }\end{array}$ \\
\hline & $\begin{array}{l}\text { Choi, Choi, Myers, } \\
\text { and Ziebart (2018) } \\
{[16]}\end{array}$ & United States & $\begin{array}{l}\text { The compatibility of financial statements improves the } \\
\text { informativeness }\end{array}$ \\
\hline & $\begin{array}{l}\text { Volkov and Sevost- } \\
\text { yanov (2014) [19] }\end{array}$ & Russia & $\begin{array}{l}\text { There is no relation between financial statements and } \\
\text { stock price dynamics for data of the past-crisis period }\end{array}$ \\
\hline & $\begin{array}{l}\text { Garanina and Ko- } \\
\text { rmiltseva (2013) [21] }\end{array}$ & Russia & $\begin{array}{l}\text { There is no difference of the Russian market efficiency for } \\
\text { different accounting standards }\end{array}$ \\
\hline Sanctions & $\begin{array}{l}\text { Naidenova and Novik- } \\
\text { ova (2018) [20] }\end{array}$ & Russia & $\begin{array}{l}\text { The imposition and prolongation of sanctions results in a } \\
\text { significant fall in share prices }\end{array}$ \\
\hline
\end{tabular}

\section{Background Information on the Russian Economic Environment}

Russia's financial market is unique in several ways. Firstly, the Moscow Exchange is relatively young compared to other major stock markets such as the NYSE, which was established in 1792, the London Stock Exchange, which was established in 1773, or Tokyo Stock Exchange established in 1878. This is because Russia started the transition from a command economy to a market economy in the 1990s. Financial markets that have existed for decades have the advantage of well-established rules and regulations as well as investors' confidence which has been developed over many years. Thus, investigation instruments for information disclosure in Russia that lead to an efficient capital market that promotes sustainable growth is a very relevant topic.

Secondly, the government owns a significant amount of shares in several major Russian firms, such as $38.4 \%$ of Gazprom shares as of 31 December 2019 [24] and $61.7 \%$ of RusHydro shares as of 31 December 2020 [25]. Moreover, the capital structure of some Russian firms contains very few free-floating shares that can be traded in the market. For example, only $20.7 \%$ of NLMK shares are available for public trading as of 17 December 2020 [26] and 43\% of Mechel Pao shares [27]. Government ownership of significant shares has both advantages and disadvantages. It can be argued that it guarantees government bailing in case the firm underperforms. Also, the government is unlikely to introduce unfavourable policies that disadvantage its own corporations. On the other hand, low free float leaves few shares in the hands of private investors. Hence, it is of interest to investigate the efficiency of the Russian financial market under these unique circumstances.

Thirdly, industrial firms make up a significant part of the Russian economy and are estimated to provide up to $31.1 \%$ of Russia's GDP, as of the first quarter of $2019^{1}$. The main Russian exports are oil and oil products, gas, coal, and wheat. Firms in the industrial sector create a higher risk of polluting the environment. These firms also require a huge initial investment that is long-term focused. In addition, these firms have foreign stakeholders, either as customers or investors. Reporting must pay special attention to the specifics of the industrial sector and the raw material markets.

${ }^{1}$ URL: https://ac.gov.ru/files/publication/a/23445.pdf, p.4 (Accessed 15 February 2021). 
Table 2. Companies listed in the RTS index between 2014 and 2020 that are incorporated in our analysis

\begin{tabular}{|c|c|c|c|}
\hline Code & Name (Eng) & Sector & Industry \\
\hline AFKS & AFK SISTEMA, Ordinary shares & Communication services & Telecom services \\
\hline AFLT & JSC AEROFLOT, Ordinary shares & Industrials & Airline \\
\hline AGRO & $\begin{array}{l}\text { ROS AGRO PLC, DR (Issuer The Bank } \\
\text { of New York Mellon Corporation) }\end{array}$ & Consumer defensive & Farm products \\
\hline AKRN & JSC Acron, Ordinary shares & Basic materials & Agricultural inputs \\
\hline ALRS & AC ALROSA, Ordinary shares & Basic materials & $\begin{array}{l}\text { Other precious metals and } \\
\text { mining }\end{array}$ \\
\hline CBOM & $\begin{array}{l}\text { CREDIT BANK OF MOSCOW, } \\
\text { Ordinary shares }\end{array}$ & Financial services & Banks, regional \\
\hline $\mathrm{CHMF}$ & Severstal, Ordinary shares & Basic materials & Steel \\
\hline DSKY & $\begin{array}{l}\text { Public Joint Stock Company Detsky } \\
\text { Mir }\end{array}$ & Consumer cyclical & Department stores \\
\hline FEES & FGC UES, JSC, Ordinary shares & Utilities & Utilities, regulated electric \\
\hline FIVE & $\begin{array}{l}\text { X5 Retail Group N.V., DR (Issuer } \\
\text { The Bank of New York Mellon } \\
\text { Corporation) }\end{array}$ & Consumer defensive & Gorcery stores \\
\hline GAZP & GAZPROM, Ordinary shares & Energy & Oil \& gas integrated \\
\hline GLTR & $\begin{array}{l}\text { Globaltrans Investment PLC, DR } \\
\text { (issuer - Citibank N.A. (NYC)) }\end{array}$ & Industrials & Railroads \\
\hline GMKN & $\begin{array}{l}\text { OJSC MMC NORILSK NICKEL, } \\
\text { Ordinary shares }\end{array}$ & Basic materials & Metals and mining \\
\hline HHRU & $\begin{array}{l}\text { HeadHunter Group PLC, DR (issuer } \\
\text { JPMorgan Chase Bank, N.A.) }\end{array}$ & Industrials & $\begin{array}{l}\text { Staffing and employee } \\
\text { services }\end{array}$ \\
\hline HYDR & JSC RusHydro, Ordinary shares & Utilities & Utilities, renewables \\
\hline IRAO & JSC Inter RAO, Ordinary shares & Utilities & Utilities, regulated electric \\
\hline $\mathrm{LKOH}$ & OAO LUKOIL, Ordinary shares & Energy & Oil \& gas integrated \\
\hline LNTA & $\begin{array}{l}\text { Lenta Ltd., DR (Issuer Deutsche Bank } \\
\text { Luxembourg S.A) }\end{array}$ & Consumer cyclical & Department stores \\
\hline LSRG & OJSC LSR Group, Ordinary shares & Real estate & Real estate, development \\
\hline MAGN & OJSC MMK, Ordinary shares & Basic materials & Steel \\
\hline MAIL & $\begin{array}{l}\text { Mail.ru Group Limited, depository } \\
\text { receipts of foreign issuer }\end{array}$ & Technology & Software, infrastructure \\
\hline MFON & Megafon, Ordinary shares & Communication services & Telecom services \\
\hline MGNT & OJSC Magnit, Ordinary shares & Consumer defensive & Discount stores \\
\hline MOEX & Moscow Exchange, Ordinary shares & Financial services & $\begin{array}{l}\text { Financial data \& stock } \\
\text { exchanges }\end{array}$ \\
\hline MSNG & MOSENERGO, Ordinary shares & Utilities & $\begin{array}{l}\text { Utilities, independent } \\
\text { power producers }\end{array}$ \\
\hline MTLR & Mechel OAO, Ordinary shares & Basic materials & Steel \\
\hline MTSS & MTS OJSC, Ordinary shares & Communication services & Telecom services \\
\hline MVID & $\begin{array}{l}\text { OJSC Company M.video, Ordinary } \\
\text { shares }\end{array}$ & Consumer cyclical & Specialty retail \\
\hline
\end{tabular}




\begin{tabular}{|c|c|c|c|}
\hline Code & Name (Eng) & Sector & Industry \\
\hline NLMK & NLMK, Ordinary shares & Basic materials & Steel \\
\hline NMTP & PJSC NCSP, Ordinary shares & Industrials & Marine shipping \\
\hline NVTK & JSC NOVATEK, Ordinary shares & Energy & Oil \& gas E\&P \\
\hline OZON & $\begin{array}{l}\text { Ozon Holdings PLC, DR (issuer - The } \\
\text { Bank of New York Mellon) }\end{array}$ & Consumer cyclical & Internet retail \\
\hline PHOR & PhosAgro, Ordinary shares & Basic materials & Agricultural inputs \\
\hline PIKK & PIK Group, Ordinary shares & Real estate & Real estate, diversified \\
\hline PLZL & PJSC Polyus, Ordinary shares & Basic materials & Gold \\
\hline POGR & $\begin{array}{l}\text { Petropavlovsk PLC, shares of a foreign } \\
\text { issuer }\end{array}$ & Basic materials & Gold \\
\hline POLY & $\begin{array}{l}\text { Polymetal International plc, Ordinary } \\
\text { shares }\end{array}$ & Basic materials & $\begin{array}{l}\text { Other precious metals \& } \\
\text { mining }\end{array}$ \\
\hline QIWI & $\begin{array}{l}\text { QIWI PLC, DR (Issuer The Bank of } \\
\text { New York Mellon Corporation) }\end{array}$ & Financial services & Credit services \\
\hline RNFT & PJSC RussNeft, Ordinary shares & Energy & Oil \& gas E\&P \\
\hline ROSN & Rosneft, Ordinary shares & Energy & Oil \& gas integrated \\
\hline RSTI & JSC Russian Grids & Utilities & Utilities, regulated electric \\
\hline RTKM & Rostelecom, Ordinary shares & Communication services & Telecom services \\
\hline RUAL & $\begin{array}{l}\text { United Company RUSAL Plc, Shares of } \\
\text { a foreign issuer }\end{array}$ & Basic materials & Aluminum \\
\hline SBER & Sberbank, Ordinary shares & Financial services & Banks, regional \\
\hline SBERP & Sberbank, Preferred shares & Financial Services & Banks, regional \\
\hline SFIN & PJSC SFI, Ordinary shares & Industrials & Rental \& leasing services \\
\hline SNGS & Surgutneftegas, Ordinary shares & Energy & Oil \& gas integrated \\
\hline SNGSP & Surgutneftegas, Preferred shares & Energy & Oil \& gas integrated \\
\hline TATN & TATNEFT, Ordinary shares & Energy & Oil \& gas integrated \\
\hline TATNP & TATNEFT, Preferred shares & Energy & Oil \& gas integrated \\
\hline TCGN & Technology General Corporation & Industrials & $\begin{array}{l}\text { Specialty industrial } \\
\text { machinery }\end{array}$ \\
\hline TRMK & $\begin{array}{l}\text { Trubnaya Metallurgicheskaya } \\
\text { Kompaniya, Ordinary shares }\end{array}$ & Basic materials & Steel \\
\hline TRNFP & Transneft, Preferred shares & Energy & Oil \& gas midstream \\
\hline UPRO & OAO E.ON Rossiya, Ordinary shares & Utilities & $\begin{array}{l}\text { Utilities, independent } \\
\text { power producers }\end{array}$ \\
\hline VTBR & JSC VTB Bank, Ordinary shares & Financial services & Banks, regional \\
\hline YNDX & Yandex N.V. & Communication services & $\begin{array}{l}\text { Internet content \& } \\
\text { information }\end{array}$ \\
\hline
\end{tabular}


Finally, Russia partially adopted IFRS in 2012 and started the process of reconciling RAS to IFRS. Most firms prepare two different reports for the same reporting period. There exist significant differences between these two standards. The existence of two standards at the same time creates room for voluntary IFRS adoption. After starting the adoption of IFRS in 2012, IFRS became mandatory for banks, public listed companies, and firms preparing consolidated financial statements [28]. However, stand-alone statements should be prepared in accordance with RAS. These complexities in regulations allow the two standards to exist. Furthermore, some industrial firms publish integrated reports that are future-oriented. These reports contain, among others, financial information, a firm's growth strategy, and a policy towards the environment. However, there is no legal framework to guide the preparation of integrated reports, nor are they mandatory.

\section{Statistical Analysis}

The objective of this research is to examine the behaviour of stock prices around the release of annual, quarterly, and unscheduled financial statements for companies listed in the Moscow Stock Exchange. More specifically, we do not focus on the prices themselves (as the comparison of absolute values is not meaningful) but consider the returns of the stocks. To this end, we propose the following hypotheses, which will be tested with different kinds of statistical tests.

Hypothesis 1 (H1): There are no abnormal returns surrounding the release of financial statements (annual, quarterly, and unscheduled).

Hypothesis 2 (H2): There are no abnormal returns surrounding the release of scheduled financial statements (annual and quarterly).

Hypothesis 3 (H3): There are no abnormal returns surrounding the release of quarterly financial statements.

\section{Sample Selection}

For our analysis, we obtain the daily stock prices of 56 companies that were present somewhen in the RTS index between 2014 and 2020 from Yahoo finance. Within this time frame, there have been changes to the composition of the index, which consists of at most 50 companies at a time. Note that we did not use all firms that were listed in the RTS index in this time frame because of the availability of the data or the duration of the firms' listing in the index. Hence, we analysed the firms given in Table 2. Note that we consider only those stock prices being within the time frames that the firms were listed in the index. In addition to the stock prices, the respective annual, quarterly, and unscheduled statements are obtained from the companies' own websites. We use the data from seven years (2014 to 2020) to analyse the relation between the behaviour of the share prices and the releases of the firms' annual, quarterly, and unscheduled financial statements with help of an event study method. This kind of method is used in related work as well, e.g., $[1 ; 4 ; 5]$. The respective industry sectors the companies belong to are given in Table 2 and the distribution of the companies among the industry sectors is depicted in Figure $1^{2}$. Concerning the events, we have a total of 1401 . Among the events, there are 315 annual statements and 918 quarterly statements, which we both denote as scheduled events. The remaining ones are unscheduled events and integrated reports.

Figure 1. Industry sectors of the firms included in the analysis

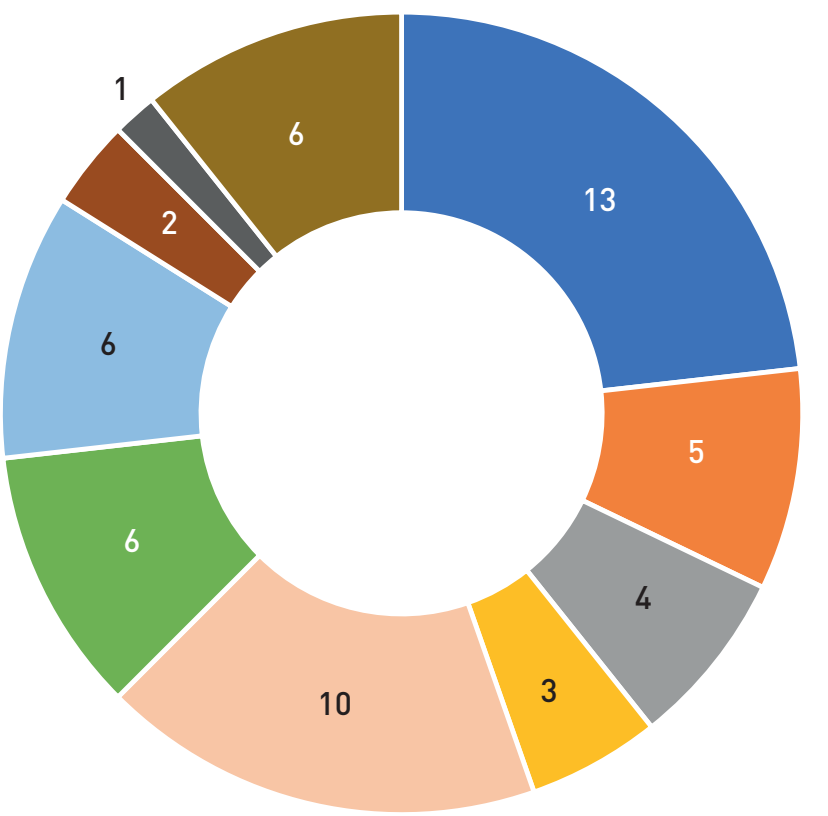

$$
\begin{array}{ll}
\text { - Basic materials } & \text { Utilities } \\
\square \text { Energy } & \text { Consumer cyclical } \\
\square \text { Technology } & \text { Industrials } \\
\square \text { Communication services } & \text { Consumer defensive } \\
\text { - Financial services } & \text { Real estate }
\end{array}
$$

\section{Event Study Methodology}

In our analysis, we distinguish between the different types of statements published by the firms we study. That is, we consider all available events for our event study, we consider scheduled events only (i.e. all quarterly and annual events), and finally, we further reduce our event set to only quarterly events. We then compare the results of these three analyses. There are clearly few annual, independent events in the data, since the annual announcements of the firms often happen around the same point of time. Therefore, we could only use a very small sample size, which possibly leads to unreliable results in the case of annual events. Independent of the event sets

${ }^{2}$ Information from Yahoo Finance as of December 2020. 
mentioned above, for each event we then define an event window where the point in time of the event is $t_{e}$. In our analysis, we set $t_{e}=0$. The event is surrounded by a preand post- phase of length $k$ that consist of points in time $t_{\text {pre }} \in\left\{t_{e}-k, \ldots, t_{e}-1\right\}$ and $t_{\text {post }} \in\left\{t_{e}+1, \ldots, t_{e}+k\right\}$, respectively, so that the period surrounding each event can be examined [29]. The event window therefore is $T_{e}=\left(t_{e}-k, \ldots, t_{e}-1, t_{e}, t_{e}+1, \ldots, t_{e}+k\right)$. In our analysis, we set $k \in\{3,7,10,12\}$ and therefore get an event window size of $7,15,21$, or 25 . Note that $k=10$ is the standard window size used in the literature, cf. [29]. Thus, we consider the $k$ days immediately preceding the event day, the event itself, and $k$ days immediately following it. When 'days' are mentioned, we always mean trading days. In Section 3.3, we use $k=10$, i.e. the standard event window size. Analyses for other event window sizes and the corresponding discussions can be found in Section 3.4.

Note that we do not distinguish between different kinds of news (good news, bad news). When we would come to the conclusion that the Russian market is efficient, we would have to analyse the different event types as inefficient artifacts could have averaged out. When we conclude that the market is not efficient (and this is indeed the case), a distinction of different types of news is not necessary. However, also in this second scenario, a distinction would be interesting in order to see how good or bad news affects the efficiency in both absolute and relative terms concerning market expectations. However, this is beyond the scope of this work.

In addition to the event window, we also define an estimation window of length $s>20$ directly preceding the event window. The estimation window is intended to show the normal performance of an asset, whereas the event window shows the presumably abnormal behaviour around the event. According to MacKinlay [29], we set the estimation window to $s=120$ which is approximately the time between two half-yearly announcements. However, we do not discount that there are other events in the estimation window as we also have, among others, quarterly announcements. Of course, in this way the estimation window does not fully reflect only normal behaviour, but as the length of the estimation window is distinctly larger than that of the event window, such effects average out fairly. Figure 2 schematically shows the timeline for our event study.

Figure 2. Timeline for the event study

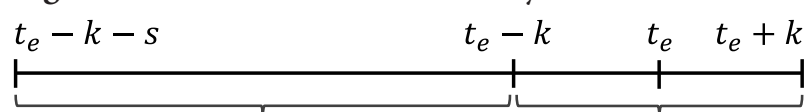

estimation window

event window

For our analysis, we assume an approximately affine linear dependency between the returns of the RTS index, i.e. the market portfolio, and any stock that is part of the index, as suggested by MacKinlay [29]. For this, we set up the following linear regression model:

$$
R_{i, t}=\alpha_{i}+\beta_{i} R_{m, t}+\varepsilon_{i, t},
$$

where $R_{i, t}$ is the return of the $i$ th asset at time $t, R_{m, t}$ is the return of the market index at time $t$, and $\varepsilon_{i, t}$ is an error term with $\mathrm{E}\left[\varepsilon_{i, t}\right]=0$ and $\operatorname{Var}\left[\varepsilon_{i, t}\right]=\sigma_{i}^{2}$. When $p_{t}$ is the value of an asset at time $t$, then the return at $t$

is $R_{t}=\frac{p_{t}-p_{t-1}}{p_{t-1}}$.

The parameters $\alpha_{\mathrm{i}}$ and $\beta_{i}$ are to be estimated through the regression using ordinary least squares (OLS) [30].

Note that we use this model, which is also known as the 'Market Model' (MM), because it is standard in the literature, see $[1 ; 29]$. As an alternative, one could use the Capital Asset Pricing Model (CAPM), however, the CAPM is very similar to the MM despite the MM having more degrees of freedom, namely in the CAPM the intercept is set to the risk free interest rate. Consequently, it is unlikely that the CAPM reduces the modelling errors, cf. [31-33]. Another alternative were multi factor models, e.g., the three factor model of Fama and French [34]. However, the risk factors for the Russian market are not readily available (see [35]). Thus, we rely on the most common choice in event studies: the Market Model - as outlined below. However, we mention that for future research both a detailed theoretical analysis of the difference between the MM and the CAPM, as well as the calculation of the Russian risk factors for multi factor models seem to be fruitful projects, but a study of both are beyond the scope of this work.

The estimation of the parameters $\alpha_{\mathrm{i}}$ and $\beta_{i}$ is done with the data of the estimation window. The normal returns are then defined as the values predicted by the model with the respective index values as input. The awaited difference between the predicted and the actual stock returns are attributed to the events, at least to a certain part. Of course, it is likely that there are discrepancies between predicted and actual values when dealing with statistical models, but these discrepancies should be Gaussian distributed. A non-Gaussian distribution of the discrepancies indicates a perceptible influence of the events. The estimations of the parameters $\alpha_{i}$ and $\beta_{i}$ are as follows:

$$
\hat{\beta}_{i}=\frac{\sum_{\tau=t_{e}-k-s}^{t_{e}-k-1}\left(R_{i, \tau}-\hat{\mu}_{i}\right)\left(R_{m, \tau}-\hat{\mu}_{m}\right)}{\sum_{t_{e}-k-s}^{t_{e}-k-1}\left(R_{m, \tau}-\hat{\mu}_{m}\right)^{2}}
$$

and $\hat{\alpha}_{i}=\hat{\mu}_{i}-\hat{\beta}_{i} \hat{\mu}_{m}$

where $\hat{\mu}_{i}=\frac{1}{s} \sum_{\tau=t_{e}-k-s}^{t_{e}-k-1} R_{i, \tau}$

is the average return of asset $i$ in the estimation window and

$\hat{\mu}_{m}=\frac{1}{s} \sum_{\tau=t_{e}-k-s}^{t_{e}-k-1} R_{m, \tau}$

is the average return of the index in the estimation window. The estimated variance of the model's error term is

$$
\hat{\sigma}_{i}^{2}=\frac{1}{\mathrm{~s}-2} \sum_{\tau=t_{e}-k-s}^{t_{e}-k-1}\left(R_{i, \tau}-\hat{\alpha}_{i}-\hat{\beta}_{i} R_{m, \tau}\right)^{2} .
$$


With the estimated returns $\hat{\mathrm{R}}_{\mathrm{i}, \tau}=\hat{\alpha}_{i}+\hat{\beta}_{i} R_{m, t}$, the (estimated $^{3}$ ) abnormal returns for stock $i$ in the event window are

$$
A R_{i, \tau}=R_{i, \tau}-\hat{R}_{i, \tau}=R_{i, \tau}-\hat{\alpha}_{i}-\hat{\beta}_{i} R_{m, \tau}
$$

for $\tau=t_{e}-k, \ldots, t_{e}+k$. Under the respective hypothesis, these are Gaussian distributed:

$$
A R_{i, \tau} \sim N\left(0, \sigma^{2}\left(A R_{i, \tau}\right)\right) .
$$

When performing the regression and estimating the model parameters, we draw events from all relevant events in our dataset, where the estimation windows of these $N$ events may not overlap. This is important to ensure that the abnormal returns are in fact Gaussian distributed under the respective hypothesis.

For the $N$ sampled events, we can calculate the average abnormal return (also: mean abnormal return; AAR) for every period $\tau \in\left\{t_{e}-k, \ldots, t_{e}+k\right\}^{4}$ :

$\overline{A R}_{\tau}=\frac{1}{N} \sum_{i=1}^{N} A R_{i, \tau}$.

These, again, can be aggregated over arbitrary time intervals $\left[\tau_{1}, \tau_{2}\right]$ within the event window to cumulative average abnormal returns (CAARs) through

$$
\overline{C A R}\left(\tau_{1}, \tau_{2}\right)=\sum_{\tau=\tau_{1}}^{\tau_{2}} \overline{A R}_{\tau},
$$

where $t_{e}-k \leq \tau_{1} \leq \tau_{2} \leq t_{e}+k$. With this notation, it is $\overline{A R}_{\tau}=\overline{C A R}(\tau, \tau)$. For these two average values, AARs and CAARs, their variances are

$$
\operatorname{Var}\left(\overline{A R}_{\tau}\right)=\frac{1}{N^{2}} \sum_{i=1}^{N} \sigma_{i}^{2}
$$

or, respectively,

$$
\operatorname{Var}\left(\overline{\operatorname{CAR}}\left(\tau_{1}, \tau_{2}\right)\right)=\sum_{\tau=\tau_{1}}^{\tau_{2}} \operatorname{Var}\left(\overline{A R}_{\tau}\right) .
$$

For a second, alternative way of calculating Equations (7) and (9) see [29]. Because the event windows of the sampled events do not overlap, the CAARs fulfill

$$
\overline{C A R}\left(\tau_{1}, \tau_{2}\right) \sim N\left(0, \operatorname{Var}\left(\overline{C A R}\left(\tau_{1}, \tau_{2}\right)\right)\right)
$$

under the respective hypothesis (in case of all events, under H1). When calculating the variance in Equation (8), $\sigma_{i}^{2}$ is substituted by its sample counterpart given in Equation (4). The test statistics for checking the hypotheses stated at the beginning of Section 3 are:

$$
\theta\left(\tau_{1}, \tau_{2}\right)=\frac{\overline{\operatorname{CAR}}\left(\tau_{1}, \tau_{2}\right)}{\left(\operatorname{Var}\left(\overline{\operatorname{CAR}}\left(\tau_{1}, \tau_{2}\right)\right)\right)^{1 / 2}}
$$

Using $\theta$, the hypotheses can be rewritten:

Hypothesis: $\theta \sim N(0,1)$.

Alternative: $\theta \nsim N(0,1)$.

We perform several statistical tests that check these hypotheses. The results, as well as preliminary insights into the data that support the approach described above, are given in the next subsection.

\subsection{Data Analysis and Results}

Before we draw samples for our analysis, we perform data cleansing procedures in a preparatory step, i.e., we skip all events with not enough history (no full estimation window), and with missing prices in the estimation and event window. After this, for 56 stocks and an event window size of $21(k=10) k$ there remain 1,359 events in total which we call effective events, and of them 1,193 scheduled events, 889 quarterly announcements and, accordingly, 304 annual announcements. A summary of the number of events is depicted in Table 3. In our program, we set $N=30$.

Table 3. Summary of the events (for event window size of 21)

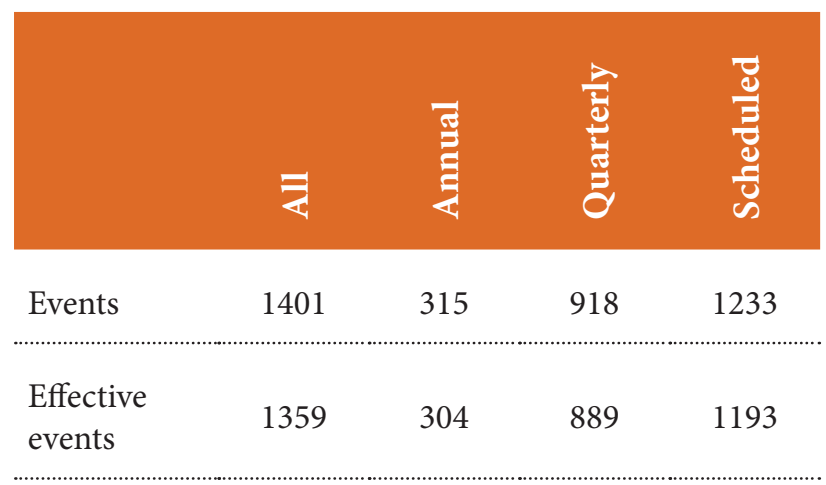

To back the assumption of an affine linear dependency between the stock returns and the index returns as stated in Equation (1), we provide four examples in Figure 3 showing the index returns plotted against the price returns in the estimation window of four events, i.e., there are 120 data points per graph. We see that the data is more or less scattered along a linear pattern. Of course, especially for the last scatterplot (bottom right), a linear dependency is debatable (in particular when taking into account its R-squared of 0.0277), but for the majority it may be accepted since the scatterplots are football-shaped. An outlier treatment is not performed here.

\footnotetext{
${ }^{3}$ In fact, a more appropriate notation would be $\widehat{A R}_{i, \tau}$, but since these values are averaged in the next step, which is marked with a bar sign, the hat sign is omitted to keep the notation simple.

${ }^{4}$ Recall that these points in time (for different events) are not the same from an absolute point of view but are shifted so that they match relatively.
} 
Figure 3. Scatterplots showing sample index returns mapped against stock returns of the estimation window of four events with R-squared given in the top right corner of each plot

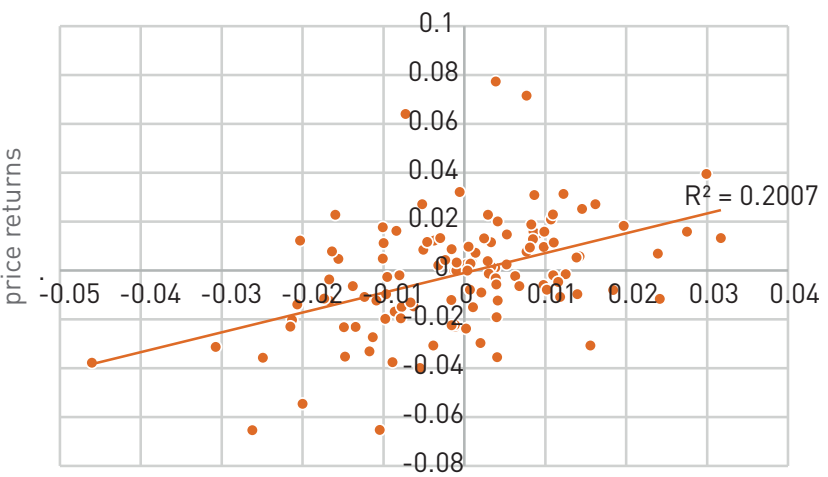

index returns

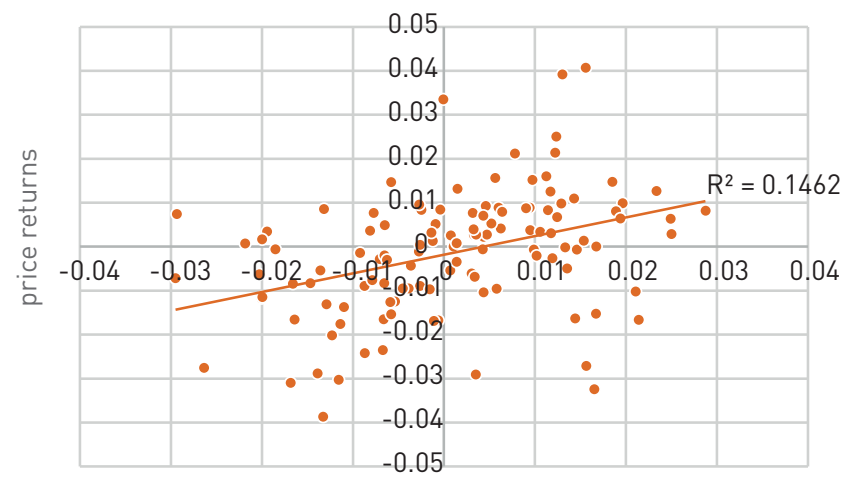

index returns

To see that the events indeed have a certain influence on the returns, we present six graphs in Figure 4 showing the AARs (Equation (6)) of six exemplary events and the corresponding CAARs (Equation (7)) where $\tau_{1}=t_{e}-k=-10$. Looking at the samples in the first row, the announcements seem to cause peaks in the AARs at the event period that also cause peaks in the CAARs. However, the drops of the AARs after the event eventually lead to a drop of the CAARs as well so that the CAARs are 0 after about 5 trading days after the event. Perhaps the news turned out not to be as good as assumed before the announcement.

The samples in the second row show serious drops of the AARs at the event period that lead to drops of the CAARs. The news announced at time $\tau=0$ seem to be bad news as after the announcement the CAARs remain more or less at the lower level (left-hand side) or even drop further (right-hand side), caused by negative AARs. In both cases, it may be that the published results did not meet the market expectations where, especially in the right case, a gap in information before the event may cause the drop of the CAARs after the event.

The graphs in the third row do not show exceptional peaks or drops of the AARs directly at the event period. Instead, the graph on the left-hand side shows a drop of the AAR already starting a few days before the announcement perhaps because the market expects the news to be bad. This drop again causes a drop of the CAAR that does not recover from the AAR's steady decrease around the event period. For the graph on the right-hand side it seems to be the case

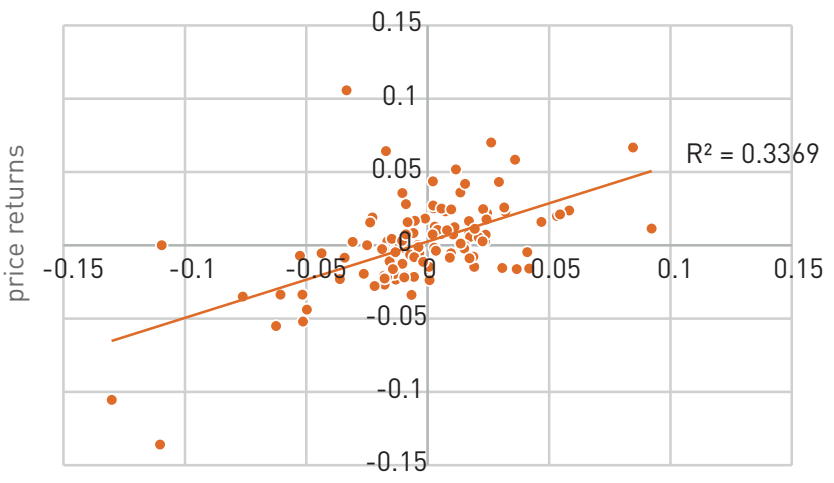

index returns

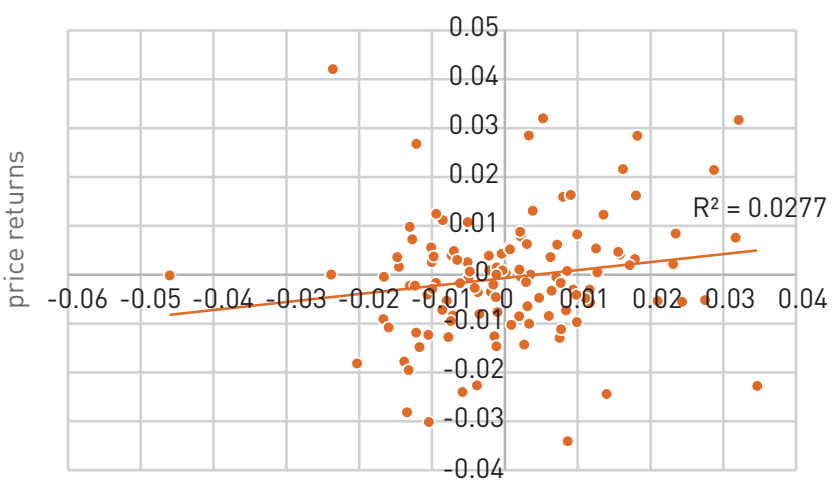

index returns

that the AAR is quite unsteady before the announcements and gets quite stable two days after the event. However, as it is constantly negative, it causes a steady drop of the CAAR. Perhaps the market was not sure about the quality of the information before it was announced and then it took two days for the price to fully reflect the market's reaction.

The impression that the events have a certain influence on the returns of stocks as seen in the graphs in Figure 4 is now backed by the results of several statistical tests that check the test statistic $\theta$ for (non-)Gaussian distribution. In fact, we conduct all tests for 1000 samples, each consisting of 30 events, in order to get more robust results. The figures are shown for only one sample. Note that in our case, for an event window length of 21 each sample consists of 231 values since $\left(\tau_{1}, \tau_{2}\right) \sim N(0,1)$ is tested for all $\tau_{1} \leq \tau_{2} T_{e}$ and $\sum_{i=1}^{21}=231$.

At first, we draw a normal Q-Q plot for one exemplary case shown in Figure 5, and notice that towards the edges, the values deviate clearly from the theoretical line. This could, in the exemplary case, indicate a right-skewed distribution (fat tails at the right, thin tails at the left). Second, we draw a kernel density plot for the same exemplary case, i.e., we construct a density out of the discrete values of the example using the Gaussian kernel shown as the red line in Figure 6 and compare the resulting density with the density of the standard Gaussian distribution (blue line). 
For the kernel density, we set the bandwidth to $0.60^{5}$. We see that the two densities differ clearly. In particular, the assumption of being right-skewed drawn from the Q-Q plot (for this data sample) is backed by the kernel density plot.

Figure 4. Graphs showing six examples, i.e. six events, of mean abnormal returns (red lines) and associated cumulative abnormal returns (blue lines)
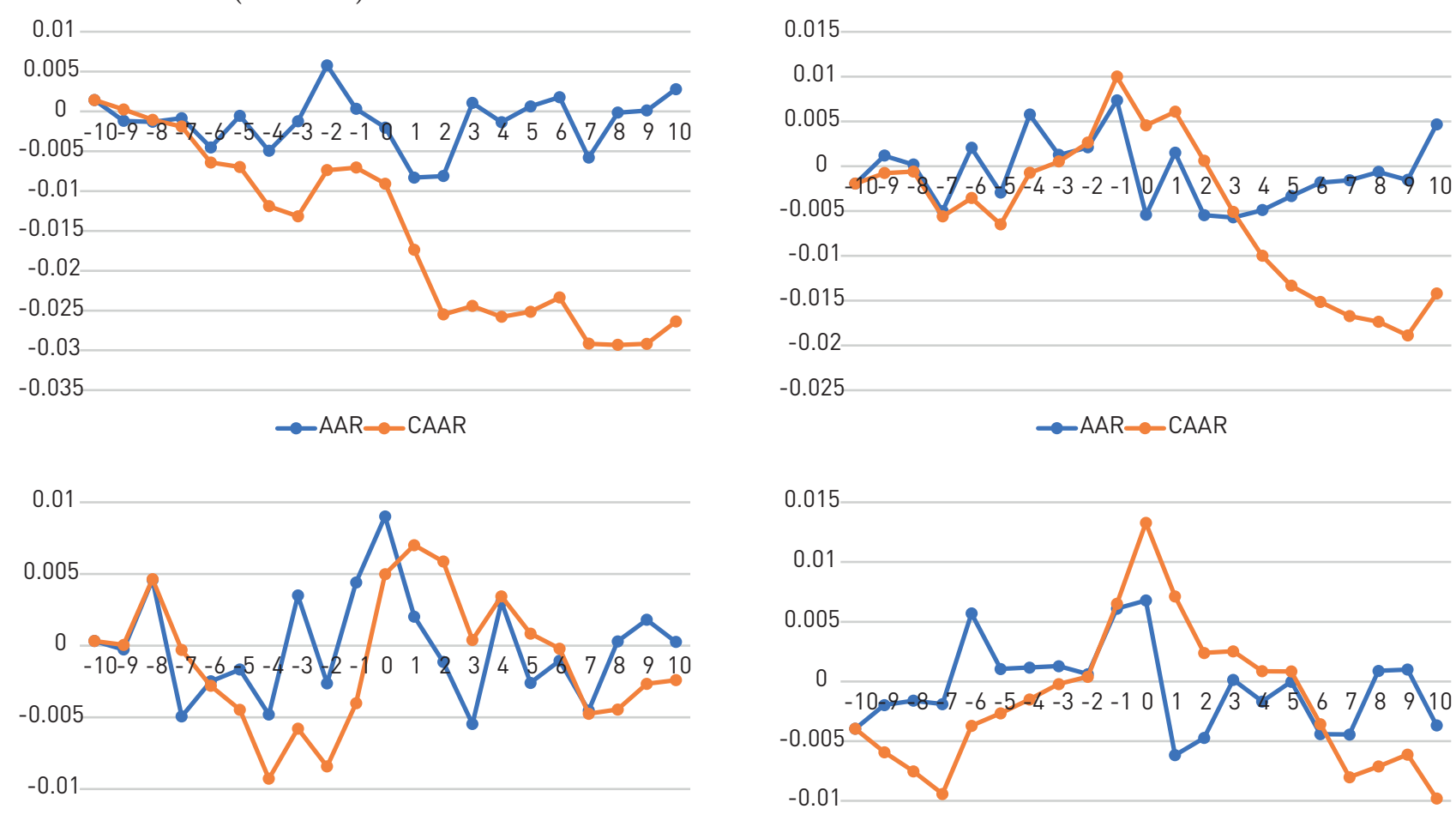

$-0.015$

$-0.015$

$\rightarrow$ AAR $\leadsto$ CAAR

$\multimap A A R \leadsto C A A R$
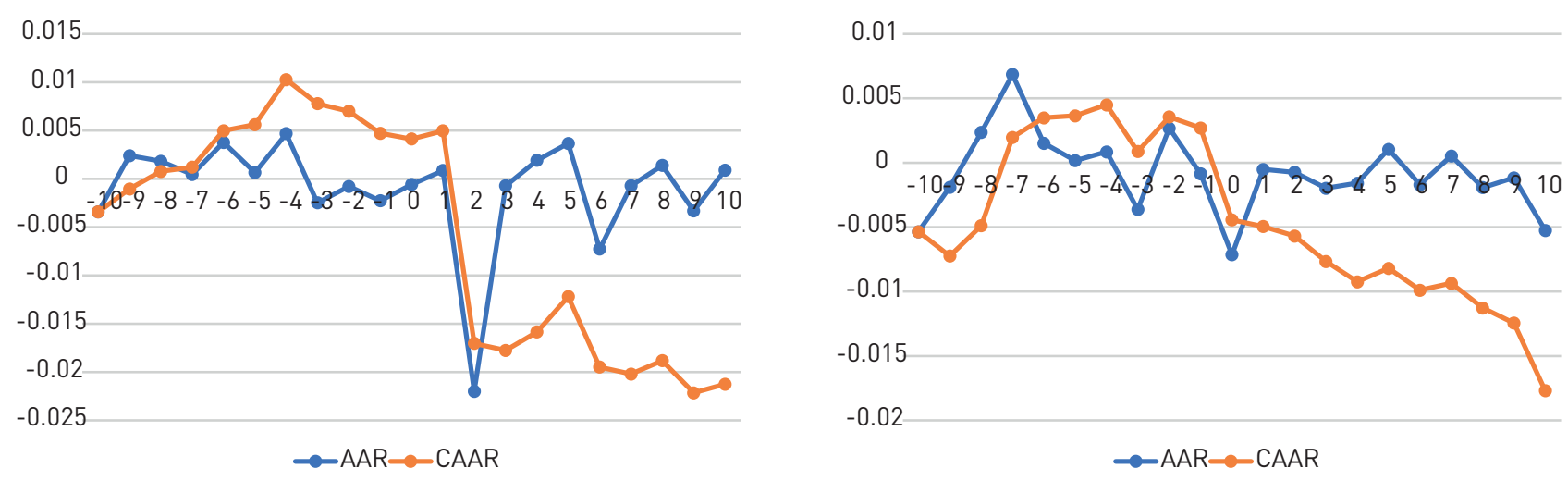

${ }^{5} \mathrm{~A}$ bandwidth of 0.60 results in the heights of the two curves being approximately the same. 
Figure 5. Q-Q plot of the test statistic for one example indicating a right-skewed distribution

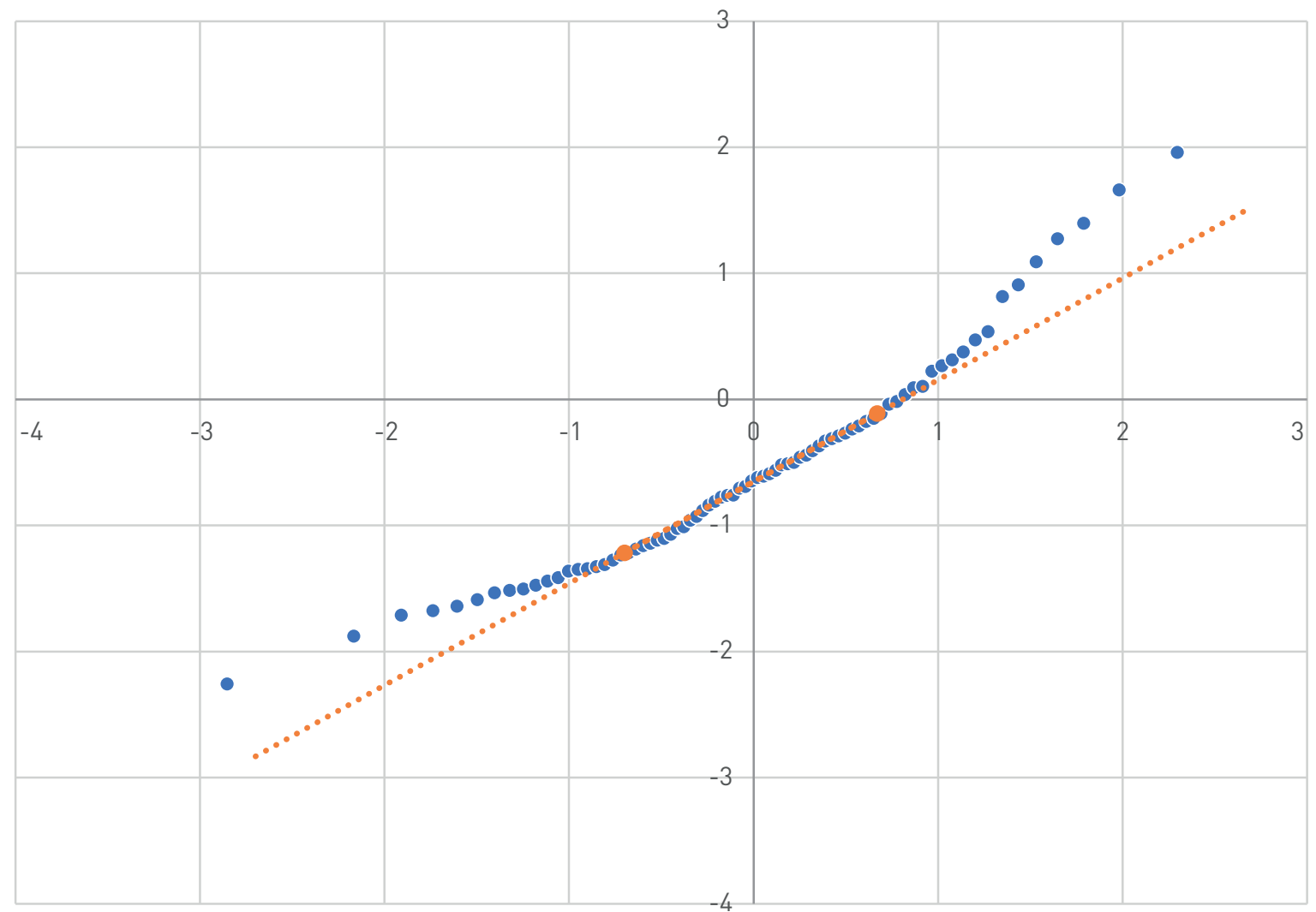

Figure 6. Kernel density plot (red) and Gaussian curve (blue) for one example that clearly differ indicating a non Gaussian distribution of the example

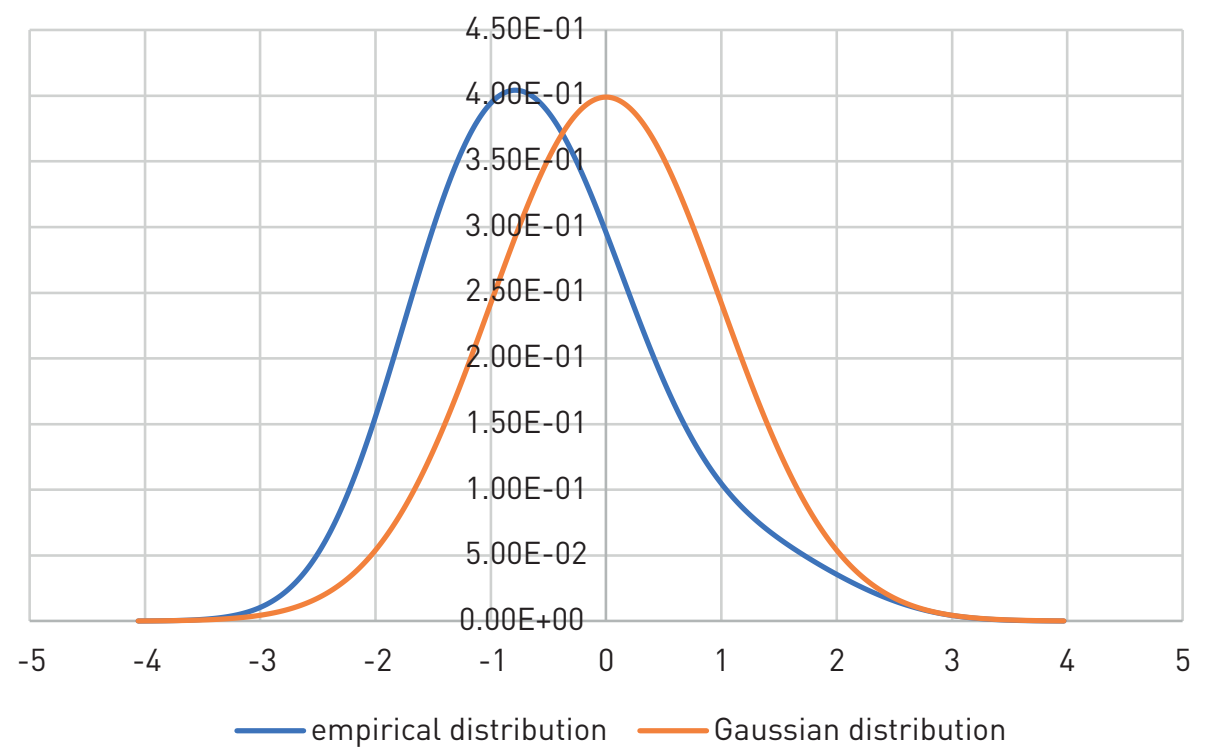

For the next step, we perform seven statistical tests for checking whether the test statistic $\theta$ is Gaussian distributed (standard normally distributed). We conduct the Kolmogorov-Smirnov test, the Lilliefors test, the Anderson-Darling test, the Jarque-Bera test, the Cramér-von Mises test, the D'Agostino-Pearson test, and the Shapiro-Wilk test. We perform all seven tests in $\mathrm{R}$ using the packages 'nortest' (Lilliefors, Anderson-Darling), 'tseries' (Jarque-Bera), 'goftest' (Cramér-von Mises), and 'PoweR' (D'Agostino-Pearson). The Kolmogorov-Smirnov test and the Shapiro-Wilk test are basic functions of $\mathrm{R}$ (in its stat-package).

For our 1000 samples (each consisting of 231 values and 30 events) we check whether the p-values of the tests are greater than or equal to a significance level of $\alpha=5 \%$ (which would mean that $\mathbf{H 1}$ may not be rejected) and count these cases. In turn, in all other cases when the p-value is below $5 \%, \mathrm{H1}$, i.e. a standard normal distribution of the abnormal returns, may be neglected. The results are shown in Table 5. 
Table 4. Number of cases supporting $\mathrm{H} 1$ resp. the Alternative with a significance level of $5 \%$

\begin{tabular}{|c|c|c|}
\hline & H1 & Alternative \\
\hline Kolmogorov-Smirnov & 30 & 970 \\
\hline Lilliefors & 0 & 1000 \\
\hline Anderson-Darling & 224 & 776 \\
\hline Jarque-Bera & 298 & 702 \\
\hline Cramér-von Mises & 27 & 973 \\
\hline D’Agostino-Pearson & 261 & 739 \\
\hline Shapiro-Wilk & 191 & 809 \\
\hline
\end{tabular}

The differences in the results probably stem from the different statistical powers of the tests. For example, the Anderson-Darling test is known to be more sensitive than the Kolmogorov-Smirnov test. However, in our tests at most about a quarter of the samples are rated to be standard normally distributed (more specifically, it cannot be disputed that the data is standard normally distributed) which means in turn that in about at least three quarters of all samples, the cumulative abnormal returns are not Gaussian distributed with a mean of zero. This indicates some abnormal effect in the returns.

For all 1,000 Monte Carlo runs, each consisting of 30 events we additionally check for the significance of the linear regression models, more specifically we test the hypothesis as to whether the slope component $\hat{\beta}$ (see Equation (2)) of each model is 0 or whether it is not 0 . In summary, we get the results presented in Table 4. For our 30,000 linear regression models, in 17,884 cases the hypothesis that $\hat{\beta}$ is 0 can be discarded with a significance level of $0.1 \%$, in additional 2,682 cases it can be discarded with a significance level of $1 \%$ and in additional 2,728 cases with a significance level of 5\%. This means that for about four fifths of all events, the market model seems to be adequate. Note that within the 30,000 linear regression models, some of them may appear more than once since in every Monte Carlo run, we randomly select 30 events independently of the previous runs.

Table 5. Significance of the linear regression market models

\begin{tabular}{|c|c|c|c|c|}
\hline Significance level & $\alpha \leq 0.1 \%$ & $0.1 \%<\alpha \leq 1 \%$ & $1 \%<\alpha \leq 5 \%$ & rest $(\alpha>5 \%)$ \\
\hline \# of cases & 17884 & 2682 & 2728 & 6706 \\
\hline
\end{tabular}

Before we conduct a more thorough discussion of the results in Section 4, we will provide a few remarks concerning the experiment and the data. As Figure 4 suggests, there are different effects of the events on the returns. But since we aggregate the returns over 30 arbitrary events, it may be the case that the effects average out leading to the result that $\mathbf{H 1}$ is not neglected (that the events do not seem to have any influence) for such a sample. Put differently, our study may underestimate the non-Gaussian distributions, i.e. the inefficiencies. This could be prevented when classifying the events into different categories (like "good news" and "bad news") as, for example, done by MacKinlay [29] and aggregating within the classes. Such an approach is intended for future work and needs a thorough investigation of each event and the market's expectations before that event. Furthermore, instead of the linear regression model used to assess the normal returns (taking the not so good R-squared values into consideration), there are other possibilities for doing this; some (e.g., constant mean return model, factor model) are mentioned by MacKinlay [29]. The assessment of the normal returns is crucial for the whole event study approach. But also here, the method partly depends on the quality and the availability of the input data.

To analyse whether the results are driven by certain event types, we limit the set of all events to sets of events of certain types, namely to scheduled events (quarterly and annual events, hypothesis H2) and to quarterly events (hypothesis H3). Considering solely annual events or unscheduled events is not possible, as there are too few events of those types in the event set. Regarding the hypotheses $\mathbf{H} \mathbf{2}$ and $\mathbf{H} 3$, we get the results shown in Table 6. For the scheduled events and the quarterly ones, we use the same input parameters (like estimation and event window size) as for the event study with events of all types. For a better comparability, we additionally show the results for $\mathbf{H} 1$.

Table 6. Number of cases supporting $\mathbf{H 1}, \mathbf{H} 2$ or $\mathbf{H 3}$ with a significance level of $5 \%$

\begin{tabular}{|c|c|c|c|}
\hline & H1 & H2 & H3 \\
\hline Kolmogorov-Smirnov & 30 & 33 & 37 \\
\hline Lilliefors & 0 & 0 & 0 \\
\hline Anderson-Darling & 224 & 224 & 188 \\
\hline Jarque-Bera & 298 & 306 & 273 \\
\hline Cramér-von Mises & 27 & 30 & 39 \\
\hline D’Agostino-Pearson & 261 & 285 & 253 \\
\hline Shapiro-Wilk & 191 & 218 & 178 \\
\hline
\end{tabular}

We observe that the scheduled events support the hypothesis that the returns are normally distributed than it is the case for all events slightly more often. The values are 
not much higher than when regarding all events. Also, for the scheduled events, the market is still not efficient. When only regarding quarterly events, the results are mixed. Two tests indicate that the quarterly announcements make the market even more efficient, whereas four tests indicate that the quarterly announcements lead to an even more inefficient market. The interpretation of the quarterly announcements' results is difficult, especially when considering the different statistical powers of the tests. Following the statistical properties of the different tests that state that the Anderson-Darling test is one of the most selective tests when testing for a Gaussian distribution (where the Jarque-Bera and Shapiro-Wilk tests are of a similar power), we might come to the conclusion that the quarterly announcements lead to a less efficient market than all scheduled events. Conversely, this means that the annual announcements are those events that mainly contribute to the efficiency of the Russian market.

\section{Results for Varying Window Sizes}

To analyse the influence of the window size on the results, we additionally conduct the analyses for other window sizes, namely $7(k=3), 15(k=7)$ and $25(k=12)$. The results of these analyses together with the results of window size $k=10$ are summarised in Table 7 .

Table 7. Number of cases supporting $\mathbf{H} \mathbf{1}$ with a significance level of $5 \%$ with an event window of size 7 , 15,21 , and 25

\begin{tabular}{|c|c|c|c|c|}
\hline & $\mathrm{H} 1,7$ & $\mathrm{H} 1,15$ & $\mathrm{H} 1,21$ & H1, 25 \\
\hline $\begin{array}{l}\text { Kolmogorov- } \\
\text { Smirnov }\end{array}$ & 278 & 79 & 30 & 21 \\
\hline Lilliefors & 0 & 0 & 0 & 0 \\
\hline $\begin{array}{l}\text { Anderson- } \\
\text { Darling }\end{array}$ & 885 & 403 & 224 & 127 \\
\hline Jarque-Bera & 936 & 525 & 298 & 209 \\
\hline $\begin{array}{l}\text { Cramér-von } \\
\text { Mises }\end{array}$ & 255 & 75 & 27 & 23 \\
\hline $\begin{array}{l}\text { D’Agostino- } \\
\text { Pearson }\end{array}$ & 880 & 458 & 261 & 201 \\
\hline Shapiro-Wilk & 855 & 374 & 191 & 130 \\
\hline
\end{tabular}

According to Fama [2], stock price adjustments at the time of an announcement are expected in an efficient market. Thus, a reduced estimation window size should lead to a lower support of the hypothesis $\mathbf{H} \mathbf{1}$ as the relative weight of the abnormal behaviour at the time of an event increases. However, our analysis finds that the smaller the event window gets, the more often $\mathbf{H} \mathbf{1}$ cannot be rejected. This is one indication that the Russian market is inefficient because the abnormal behaviour is not observable at the event date but either too early or too late. Further, there is a technical issue why $\mathbf{H} \mathbf{1}$ is less rejected in an inefficient market when the event window gets smaller. The smaller the event window gets, the more likely it is that an abnormal behaviour preceding the event is part of the estimation window. Then this abnormal behaviour is part of the learned market model and the behaviour within the event window is not recognised as abnormal.

\section{Discussion of the Results}

Our results indicate that it is possible for a trader to buy/ sell securities before the event and make a profit out of accumulated abnormal returns. We observe three different reactions to events. Firstly, a drop in the AARs indicating that the market was expecting better news than they received. Secondly, a rise in the AARs indicating that the information was received well in the market, and thirdly a case where the publication does not seem to have any effect on stock prices. Statistical tests confirmed that stock prices respond to the publication of annual, quarterly, and other financial statements. In particular, scheduled publications seem to lead to a slightly more efficient market than all publications (scheduled and unscheduled ones). Regarding annual and quarterly announcements, we cannot point to a clear difference as the statistical tests give ambiguous results. Future research may also take the work of Alderson and Betker [36], Marks and Musumeci [37] as well as Aktas, de Bodt, and Cousin [38] into account.

These results are consistent with those of Dsouza and Mallikarjunappa [22], Rajakulanajagam [15], and Ball and Brown [1]. However, Dsouza and Mallikarjunappa [22] use a mean-adjusted model, a market-adjusted model, and an OLS market model. They observe three different types of news, namely: good news, bad news, and neutral news. They use a 'Run' test, a 'Sign' test, and a 't-test' for statistical significance and find AARs to be insignificant under the mean adjusted model, while CAARs are significant. This means that the market does not absorb new information quickly. Rajakulanajagam [15] argues that the reaction on day zero showing the response of stock prices on publication of financial statements is an indication of market efficiency, because the market reacts quickly to this new information, cf. [2]. However, our results indicate CAARs that extend beyond the event day in the case of good news or bad news which is inconsistent with the efficient market hypothesis (EMH) [3; 4]. Hence, our results are in line with Ball and Brown [1], who find that earning figures contain very useful information that is not reflected in stock prices immediately.

These results contradict those of Brookfield and Morris [12], Firth [13], Foster [10], May [11], and Opong [8] who conclude that stock prices adjust rapidly to the publicly available information, consistent with the EMH. Firth [13] investigates the information content of financial statements and concludes that both annual and interim financial reports contain substantial information, which is quickly absorbed in the market. Foster [10] observes that a market's reaction to earning announcements appears 
to be concentrated on a two days trading period. These results seem to suggest that developed capital markets absorb new information quickly, whereas emerging markets do not.

For an efficient allocation of resources in the capital market, it is necessary to reduce the information asymmetry and improve procedures, forms, and requirements for financial statements that ensure an adequate information flow to financial market participants in order to decrease the difference between the fundamental and the market value. A possible area of improvement would be the refinement of reporting standards. While it is clear that IFRS and RAS are significantly different, further research is needed to assess whether reporting standards (or at least different reporting schemes) have a significant impact on market efficiency. Besides this, the enforcement of the standards by authorities and a mandatory versus a voluntary adoption are other areas that need investigation. Reporting must respond to the needs of Russian industrial firms. These firms have to invest in long-term projects that reap benefits in the long run (see Section 2.2). Shortterm periodical reporting may not be appropriate for long-term plans, which is why future-oriented integrated reports may be more suited to address the needs of Russian industrial firms. However, further research on this is necessary, too.

\section{Conclusion}

This study investigates the effects of financial reporting on stock prices of the firms listed on the Moscow Stock Exchange. Our research analyses 1000 samples, each consisting of 30 events, independent of the underlying stocks/ firms and analyses the relation between the behaviour of the share prices and the release of the firms' annual, quarterly, and unscheduled financial statements. We use an ordinary least squares market model to estimate market parameters and calculate abnormal returns. These abnormal returns and cumulative abnormal returns are then aggregated across firms for each date in the event window. For all time intervals, the aggregation over time should be Gaussian distributed when assuming no abnormal effect of the events on the prices. This is analysed graphically with Q-Q plots and kernel density estimators, as well as with statistical hypotheses tests. To get more robust results, we analyse 1000 samples and count the cases supporting a (non-) Gaussian distribution. Additionally, we perform comparability tests for the type of events (scheduled, quarterly) and robustness tests for the length of the event window.

We find that in the majority of cases there is a significantly abnormal relationship between the publication of financial statements and the price of the shares. The results show that the Russian stock market responds significantly to new information. This means analysts and fund managers can use new information to predict future stock returns and, thus, construct profitable portfolios. There is a possibility of generating abnormal returns using publicly available information, which indicates that the Russian financial market is to some degree inefficient, which might lead to instabilities. Steps have to be taken to reduce information asymmetry, thereby reducing the difference between the fundamental and the market value of securities. We argue that the inefficiency in the market is a result of an information asymmetry. This asymmetry can be reduced by improving the information content of financial statements in Russia.

Following Choi, Choi, Myers, and Ziebart [16] and Hayati [17] the compatibility and informativeness of financial statements must be increased. It might be useful to investigate the differences concerning the information content and the compatibility between financial statements in Russia and in some developed markets that are assumed to be efficient.

This study raises several questions for further investigation. Firstly, Russia adopted IFRS in 2012 and started the process of reconciling RAS to IFRS. The majority of Russian firms have to prepare RAS statements parallel to IFRS statements. Thus, a future research could investigate whether there is a difference between the two standards' influences on the efficiency of the Russian stock market. Secondly, financial reporting must pay special attention to the specifics of the industrial sector and the raw material markets. Future research may investigate the adequacy of future-oriented integrated reports in meeting the needs of Russian industrial firms. Thirdly, Fama and French [39] investigate effects of several parameters such as the size of the firm, book to market equity, and the earning to price ratio on average stock returns. We recommend analysing the effect of these or similar variables on the Russian market.

\section{Disclaimer}

The opinions in this report expressed by Michaela Baumann are her own and not necessarily those of her employer. Michaela Baumann's employer does not guarantee the accuracy or reliability of the information provided herein.

\section{References}

1. Ball R., Brown P. An Emphirical Evaluation of Accounting Income Numbers. Journal of Accounting Research. 1968;6(2):159-178. https://doi. org/10.2307/2490232

2. Fama EF. Efficient Capital Markets: II. The Journal of Finance. 1991;46:1575-1617. https://doi. org/10.1111/j.1540-6261.1991.tb04636.x

3. Fama EF. A Review Of Theory And Empirical Work. The Journal of Finance. 1970;25(2):383-417. https:// doi.org/10.2307/2325486

4. Fama EF, Fisher L, Jensen M, Roll R. The Adjustment Of Stock Prices To New Information. International Economic Review. 1969;10(1):1-21. https://doi. org/10.2307/2525569 
5. Khanal A, Mishra A. Stock Price Reactions to Stock Dividend Announcements: A case from a Sluggish Economic Period. North American Journal of Economics and Finance. 2017 Nov;42:338-345. https://doi.org/10.1016/j.najef.2017.08.002

6. Kothari SP, Warner JB. The Econometrics of Event Studies. 2004. http://dx.doi.org/10.2139/ssrn.608601

7. Jones N, Bacon, F. Surprise Earnings Announcement: A Test Of Market Efficiency. Academy of Accounting and Financial Studies. Allied Academies International Conference. 2007;12(1):43-48. http://citeseerx.ist.psu. edu/viewdoc/download?doi=10.1.1.614.3435\&rep=re p1\&type $=$ pdf $\#$ page $=48$

8. Opong K. Hourly Share Price Response to the Release of Preliminary Annual Financial Reports: Some UK Evidence. British Accounting Review. 1996;28(3):187202. https://doi.org/10.1006/bare.1996.0014

9. Beaver W. The Information Content of Annual Earnings Announcements. Journal of Accounting Research. 1968;6:67-92. https://doi. org/10.2307/2490070

10. Foster G. Quarterly Accounting Data : Time-Series Properties and Predictive- Ability Results. The Accounting Review. 1977;52(1):1-21. https://www. jstor.org/stable/246028

11. May R. The Influence of Quarterly Earnings Announcements on Investor Decisions as Reflected in Common Stock Price Changes. Journal of Accounting Research. 1971;9:119-163. https://doi. org/10.2307/2490094

12. Brookfield D, Morris R. The Market Impact Of Uk Company News Announcements. Journal Of Business Finance \& Accounting. 1992;19(4):585-602. https:// doi.org/10.1111/j.1468-5957.1992.tb00646.x

13. Firth M. The Relative Information Content of the Release of Financial Results Data by Firms. Journal of Accounting Research. 1981;19(2):521-529. https://doi. org/10.2307/2490878

14. Menike M, Wang M. Stock Market Reactions to the Release of Annual Financial Statements Case of the Banking Industry in Sri Lanka. European Journal of Business and Management. 2013;5(31):75-86. https:// iiste.org/Journals/index.php/EJBM/article/view/9467

15. Rajakulanajagam N. Stock Market Reaction to the Release of Annual Financial Statements: A Study on Selected Listed Banking Finance and Insurance Companies in Sri Lanka. 2015. https://ssrn.com/ abstract $=3321020$

16. Choi J, Choi S, Myers L, Ziebart D. Financial Statement Comparability and the Informativeness of Stock Prices About Future Earnings. Contemporary Accounting Research. 2018;36(1):389-417. https://doi. org/10.1111/1911-3846.12442
17. Hayati N. Financial Statement Report and its Effect on Stock Price (Case study on banking industy). Widyatama University. 2010;9(Spring 2010):107112. https://repository.widyatama.ac.id/xmlui/ handle/123456789/1333

18. Berezinets IV, Bulatova LA, Ilina YB, Smirnov MV. Stock Market Reaction to Dividend Surprises: Evidence from Russia. Working Papers 6427, Graduate School of Management, St. Petersburg State University. 2015. https://ideas.repec.org/p/sps/ wpaper/6427.html

19. Volkov VV, Sevostyanov VN. Stock Market's Reaction to the Forecasts of a Company's Financial Results. Young Scientist. 2014;8(67). https://moluch.ru/ archive/67/11535/

20. Naidenova I, Novikova A. The Reaction of Russian Public Companies' Stock Prices to Sanctions Against Russia. Journal of Corporate Finance Research. 2018;12(3):27-38. https://ssrn.com/abstract $=3346340$

21. Garanina TA, Kormiltseva PS. The Effect of International Financial Reporting Standards (IFRS) Adoption on the Value Relevance of Financial Reporting: a Case of Russia. Accounting in Central and Eastern Europe. 2013;13:27-60. https://doi. org/10.1108/S1479-3563(2013)0000013007

22. Dsouza J, Mallikarjunappa T. Quarterly Earnings and Stock Prices Reactions - A Study of BSE500 Companies. Amity Journal of Finance. 2016;1(11):9-35. https://amity.edu/UserFiles/ admaa/141Paper\%202.pdf

23. Naser K, Nuseibeh R. Quality of financial reporting: evidence from the listed Saudi nonfinancial companies. The International Journal of Accounting. 2003;38:41-69. https://doi.org/10.1016/S00207063(03)00002-5

24. Gazprom. Equity Capital Structure. 2020. https:// www.gazprom.com/investors/stock/structure/ (Accessed 15 February 2021)

25. RusHydro. Stock information. 2020. http://www. eng.rushydro.ru/investors/stock-market/capital/ (Accessed 15 February 2021)

26. NLMK. Structure of share capital as of 31 August 2020. 2020. https://nlmk.com/en/about/governance/ share-capital-structure/ (Accessed 15 February 2021)

27. Mechel. Shareholder Structure. 2020. https://www. mechel.com/shareholders/info/capital/ (Accessed 15 February 2021)

28. Kim O. Russian Accounting System: Value Relevance of Reported Information and the IFRS Adoption Perspective. The International Journal of Accounting. 2012;48:525-547. https://doi.org/10.1016/j. intacc.2013.10.007 
29. MacKinlay A. Event Studies in Economics and Finance. Journal of Economic Literature. 1997;35(1):13-39. http://www.jstor.org/ stable/2729691

30. Sharpe F. Capital Asset Prices: A Theory of Market Equilibrium Under Conditions of Risk. The Journal of Finance. 1964;19(3):425-442. https://doi. org/10.1111/j.1540-6261.1964.tb02865.x

31. Brown SJ, Warner JB. Measuring Security Price Performance. Journal of Financial Economics. 1980;8(3):205-258. https://doi.org/10.1016/0304$405 \mathrm{X}(80) 90002-1$

32. Brown SJ, Warner JB. Using Daily Stock Returns: The Case of Event Studies. Journal of financial economics. 1985;14(1):3-31. https://doi.org/10.1016/0304405X(85)90042-X

33. Fama EF. Market Efficiency, Long-Term Returns, and Behavioral Finance. Journal of Financial Economics. 1998;49(3):283-306. https://doi.org/10.1016/S0304405X(98)00026-9

34. Fama EF, French KR. Common Risk Factors in the Returns on Stocks and Bonds. Journal of Financial Economics. 1993;33(1):3-56. https://doi. org/10.1016/0304-405X(93)90023-5

35. French KR. Current Research Returns. 2021. http:// mba.tuck.dartmouth.edu/pages/faculty/ken.french/ data_library.html (Accessed 1 February 2021)

36. Alderson MJ, Betker BL. The Specification and Power of Tests to Detect Abnormal Changes in Corporate Investment. Journal of Corporate Finance. 2006;12(4):738-760. https://doi.org/10.1016/j. jcorpfin.2005.07.001

37. Marks JM, Musumeci J. Misspecification in event studies. Journal of Corporate Finance. 2017;45:333341. https://doi.org/10.1016/j.jcorpfin.2017.05.003

38. Aktas N, de Bodt E, Cousin JG. Event studies with a contaminated estimation period. Journal of Corporate Finance. 2007;13(1):129-145. https://doi. org/10.1016/j.jcorpfin.2006.09.001

39. Fama EF, French KR. The Cross-Section of Expected Stock Returns. The Journal of Finance. 1992;47(2):427-465. https://doi.org/ doi:10.1111/j.1540-6261.1992.tb04398.x 